\title{
Comparative Study on the Effect of Factor V Leiden and Prothrombin Gene Polymorphism in Preeclampsic Cases
}

\author{
Rizk Ahmed EL Baz**, Manal Mohamed Ramadan*, Eman Fayad***, Ali Ali Shaltot**, \\ andEffat Mahmoud EL Shershaby * \\ * Faculty of Science, Zoology department at Mansoura University. \\ ** Faculty of Medicine, Genetic department at MansouraUniversity. \\ *** Faculty of Science, Zoology department at Mansoura University, assistant professor at \\ Biotechnology department, Faculty of science at Taif University
}

\begin{abstract}
:
Objective: To identify polymorphism of Factor V Leiden and Prothrombin gene in women suffering from preeclampsia.

Study design: From 142 pregnant women we identified 92 women suffering from preeclampsia and 50 healthy controls with normal pregnancy matched for age and socioeconomic status, preeclampsic patient classified as mild preeclampsia 42(45.7\%) and severe preeclampsia $50(54.3 \%)$. Blood samples were tested for DNA polymorphism affecting thrombophilia Factor V Leiden and Prothrombin gene polymorphism.

Results: Heterozygous AG genotype showed a significant high frequency among preeclampsic patients $(20.7 \%)$ compared to controls $(4.0 \%),(\mathrm{OR} 6.2, \mathrm{P}=0.006)$ regarding to Prothrombin gene but: Factor V Leiden, AG genotype showed (8.7\%) of preeclampsic patients which was absent in any of the controls.
\end{abstract}

Key words: Factor V Leiden, Prothrombin gene, preeclampsia.

\section{Introduction:}

Preeclampsia defined as pregnancyinduced protein uric hypertension with onset of clinical symptoms beyond 20 weeks gestation, it is a serious pregnancy complication and a leading cause of maternal mortality and fetal perinatal morbidity.$^{(1,2)}$ Clinical disease may also be associated with abnormalities of the central nervous system, the liver, the kidneys, and intra-vascular disseminated coagulation. ${ }^{(3,4,5)}$

Factor V Leiden (FVL) and the prothrombin gene mutations are the first and second most common genetic abnormalities associated with increased risk of deep venous thrombosis. ${ }^{(6)}$

Prothrombin gene mutation is one of the most common genetic alterations associated with venous thrombosis (7) Thrombotic events frequently appear to result from a multifactorial process, in which acquired risk factors, such as surgery, pregnancy, trauma, immobilization, and malignancy, interact with inherited abnormalities of coagulation. ${ }^{(8)}$

\section{Materials and Methods:}

This study was reviewed and approved by the Mansoura University of science, and informed consent was obtained from all the studygroups.

\section{Study groups:}

\section{Group I (Patients):}

This group comprised 92 cases selected randomly from those attending Obstetricsand Gynecology Department at Mansoura University Hospitals, complaining of preeclampsia. They were collected through one year from August 2008. Age of the patients ranged from 20-28 years (mean age $23.91 \pm 2.1$ years). They were classified into mild preeclampsia, 42 cases $(45.7 \%)$ and severe preeclampsia, 50 cases $(54.3 \%)$.

\section{Group II (control group):}

This group included 50 healthy females, with normal pregnancy, matched for age, residency and socioeconomic status.

\section{Methods:}

\section{DNA extraction:}

The Generation DNA Purification Capture Column Kit is based on a proprietary system that uses two reagents, a DNA 
Purification Solution (Solution 1) and a DNA Elution Solution (Solution 2) along with a specially formulated purification matrix. Following removal of contaminants, the DNA was released from the matrix using DNA Elution Solution and heat. Samples of purified DNA are ready for analysis and did not require precipitation.

\section{Polymerase chain reaction:}

PCR is based on the enzymatic amplification of a fragment of DNA that is flanked by two primers (short oligonucleotide) that hybridize to the opposite strands of the target sequence and primer extention according to the complementary sequence by using enzyme DNA polymerase.

Primer sequences, PCR conditions and digestion of each polymorphism studied: Factor V Leiden G1691A and Prothrombin G20210A:

For evaluation of Factor $\mathrm{V}$ Leiden G1691A and Prothrombin G20210A, the following primers were used:

FV common (5 - GGA CTA CTT GAC

AAT TAC TGT TCT CTT G -3`).

FV WT (5`-GCA GAT CCC TGG ACA GAC G -3').

FV mutant (5`- GCA GAT CCC TGG ACA GAC A -3’).

PT common (5 - TCT AGA AAC AGT

TGC CTG GCA G-3`).

PT WT (5`- GCA CTG GGA GCA TTG AGG ATC-3`).

PT mutant (5 - GCA CTG GGA GCA TTG AGG ATT-3`).

FIX-1 (5 - CTC CTG CAG CAT TGA GGG AGA TGG ACA TT-3`).

FIX-2 (5 - CTC GAA TTC GGc AAG CAT ACT CAA TGT AT-3').

Factor V Leiden G1691A and prothrombin gene mutations G20210A were analyzed using a multiplex allele-specific PCR amplification ..9,10) DNA samples extracted from peripheral blood obtained from individuals known to have factor $\mathrm{V}$ and prothrombin mutations were used as positive controls. The DNA extracted from all cases was also subjected to amplification of a region of factor IX gene as an internal control for assessment of the quality of the extracted DNA.

- Each dNTP, $500 \mathrm{nmol} / \mathrm{L}$ of each primer, and 2.5 units of Taq DNA polymerase (Amplitaq Gold, PerkinElmer Cetus, Norwalk, Conn).

- DNA was initially denatured for 10 minutes at $95^{\circ} \mathrm{C}$, and then 10 cycles were performed as follows: $94^{\circ} \mathrm{C}$ for 30 seconds, $60^{\circ} \mathrm{C}$ for 30 seconds, and $72^{\circ} \mathrm{C}$ for 1 minute.

- Then, 25 cycles were performed as follows: $94^{\circ} \mathrm{C}$ for 30 seconds, $55^{\circ} \mathrm{C}$ for 30 seconds, and $72^{\circ} \mathrm{C}$ for 1 minute.

- The PCR amplification was completed by a final extension at $72^{\circ} \mathrm{C}$ for 7 minutes.

- Amplification of the factor $\mathrm{V}$ and prothrombin genes resulted in 152base pair (bp) and 340-bp products, respectively.

- The internal amplification control (i.e. the region of the factor IX gene) resulted in a 250-bp product.

The amplified products were then electrophoresed in 2\% agarose gel, Stained with ethidium bromide, and visualized under UV light.

\section{Statistical analysis:}

All data were collected and tabulated and statistically analyzed using SPSS statistical computer package version 10 software. Quantitative variable were expressed as mean $\pm \mathrm{SD}$, while the qualitative variables were presented as numbers and percents. Comparison of qualitative data was done using Fisher's Exact test. Odds ratio (OR) and 95\% confidence interval $(95 \% \mathrm{CI})$ were also used to compare the frequency among study and control groups to assess risk factors. Statistical significance was set at $\mathrm{P}<0.05$. 


\section{Results}

Table (1):Descriptive data of preeclampsic cases

\begin{tabular}{||ll||}
\hline \multicolumn{1}{||}{ Number } & Cases \\
\hline \hline Age (Years) & 92 \\
$\quad$ Mean \pm SD & \\
$\quad$ Median & $23.91 \pm 2.1$ \\
$\quad$ Range & 24.00 \\
Diagnosis & $20.00-28.00$ \\
$\quad$ MildPreclampsia & \\
Sever preclampsia & $42(45.7 \%)$ \\
Parity & $50(54.3 \%)$ \\
Primigravida & \\
Multigravida & $51(55.4 \%)$ \\
Family history (positive/negative) & $41(44.6 \%)$ \\
Systolic blood pressure & $42 / 50$ \\
140 - 160 & $62(67.4 \%)$ \\
$>160 \quad 30(32.6 \%)$ \\
Diastolic blood pressure & \\
90 - 110 & $32(34.8 \%)$ \\
$>110$ & $60(65.2 \%)$ \\
Gestational age & \\
$\quad \leq 36$ week & $66(71.7 \%)$ \\
$>36$ week & $26(28.3 \%)$ \\
\hline
\end{tabular}

Table (2): Comparsionbetween prothrombin gene and factor V Leiden polymorphism among preeclampsic cases and controls.

\begin{tabular}{|c|c|c|c|c|c|}
\hline \multirow[b]{2}{*}{ PT } & \multicolumn{3}{|c|}{ Genotypes } & \multicolumn{2}{|c|}{ Alleles } \\
\hline & $\begin{array}{c}\text { GG } \\
\mathbf{n}(\%)\end{array}$ & $\begin{array}{c}\mathbf{A G} \\
\mathbf{n}(\%)\end{array}$ & $\begin{array}{c}\mathbf{A A} \\
\mathbf{n}(\%) \\
\end{array}$ & $\begin{array}{c}\mathbf{G} \\
\mathbf{n}(\%) \\
\end{array}$ & $\begin{array}{c}\mathbf{A} \\
\mathbf{n}(\%) \\
\end{array}$ \\
\hline $\begin{array}{c}\text { Cases } \\
(\mathrm{n}=92)\end{array}$ & $68(73.9 \%)$ & $19(20.7 \%)$ & $5(5.4 \%)$ & $155(84.2 \%)$ & $29(15.8 \%)$ \\
\hline $\begin{array}{c}\text { Controls } \\
(\mathbf{n}=\mathbf{5 0})\end{array}$ & $48(96.0 \%)$ & $2(4.0 \%)$ & $0(0.0 \%)$ & $98(98.0 \%)$ & $2(2.0 \%)$ \\
\hline $\mathbf{P}$ & $0.001 *$ & $0.006^{* *}$ & 0.165 & $0.0002 * *$ & $0.0002 * *$ \\
\hline \multirow[t]{2}{*}{ OR $(95 \%$ CI $)$} & $0.1(0.02-0.52)$ & $6.2(1.39-28.05)$ & $6.09(0.32-112.71)$ & $0.1(0.02-0.46)$ & $9.1(2.13-39.2)$ \\
\hline & \multicolumn{3}{|c|}{ Genotypes } & \multicolumn{2}{|c|}{ Alleles } \\
\hline FV & $\begin{array}{c}\text { GG } \\
\mathbf{n}(\%)\end{array}$ & $\begin{array}{c}\mathbf{A G} \\
\mathbf{n}(\%)\end{array}$ & $\begin{array}{c}\mathbf{A A} \\
\mathbf{n}(\%) \\
\end{array}$ & $\begin{array}{c}\mathbf{G} \\
\mathbf{n}(\%)\end{array}$ & $\begin{array}{c}\mathbf{A} \\
\mathbf{n}(\%) \\
\end{array}$ \\
\hline $\begin{array}{c}\text { Cases } \\
(n=92)\end{array}$ & $83(90.2 \%)$ & $8(8.7 \%)$ & $1(1.1 \%)$ & $174(94.6 \%)$ & $10(5.4 \%)$ \\
\hline $\begin{array}{c}\text { Controls } \\
(\mathbf{n}=50)\end{array}$ & $50(100.0 \%)$ & $0(0.0 \%)$ & $0(0.0 \%)$ & $100(100.0 \%)$ & $0(0.0 \%)$ \\
\hline $\mathbf{P}$ & $0.02 *$ & 0.05 & 1.0 & $0.01 *$ & $0.01 *$ \\
\hline OR $(95 \% \mathrm{CI})$ & $0.08(0.004-1.529)$ & $10.1(0.57-179.9)$ & $1.65(0.066-41.43)$ & $0.08(0.004-1.42)$ & $12.09(0.7-208.7)$ \\
\hline
\end{tabular}

$\mathrm{n}=$ number of cases, $(\%)=$ percentage of cases, $\mathrm{OR}(95 \% \mathrm{CI})=$ Odds ratio and $95 \%$ confidence interval., Significance using Fisher's Exact Test: **p $<0.05$ (highly significant). 


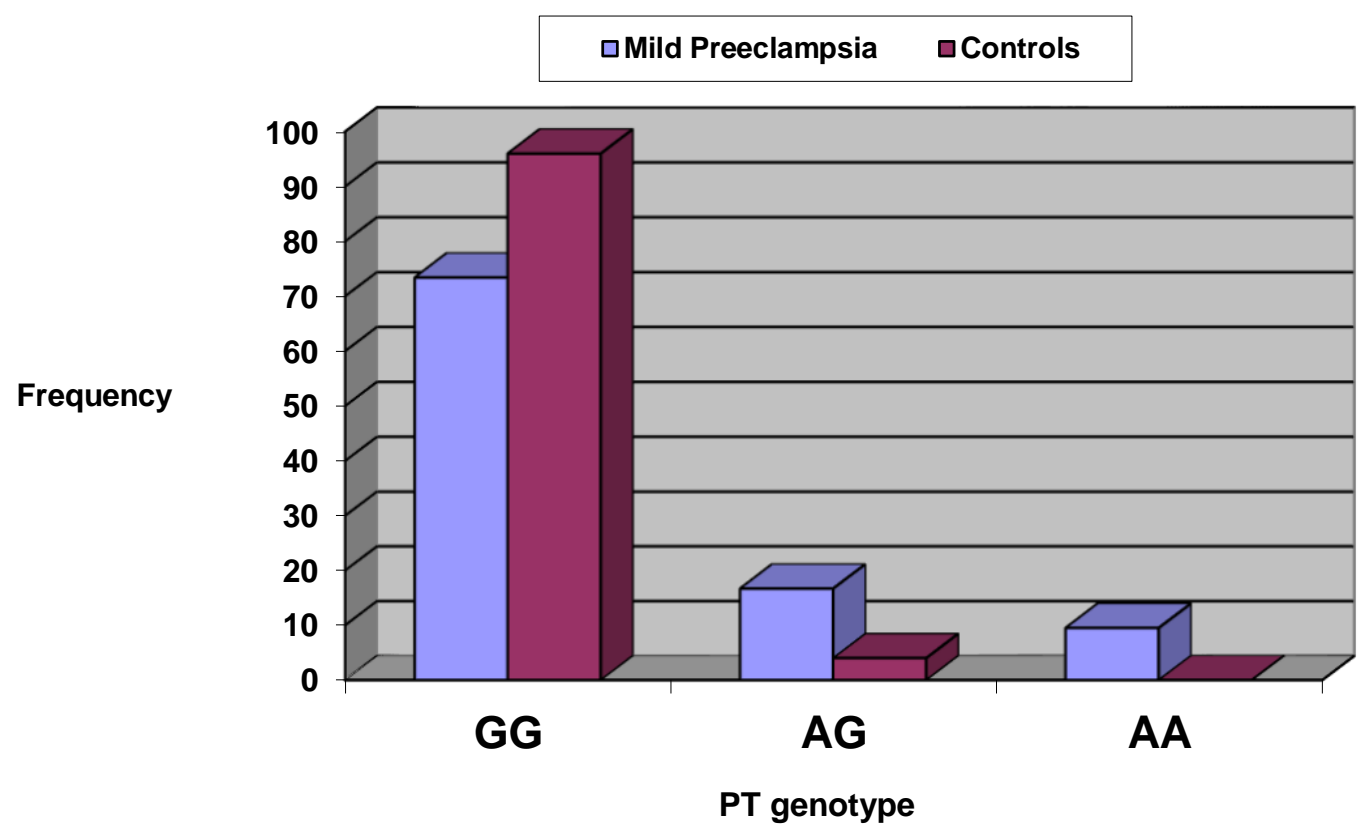

Fig. (1): Comparsion between genotype allele in mild preeclampsic cases and healthy controls regarding their distribution and frequency of Prothrombin gene.

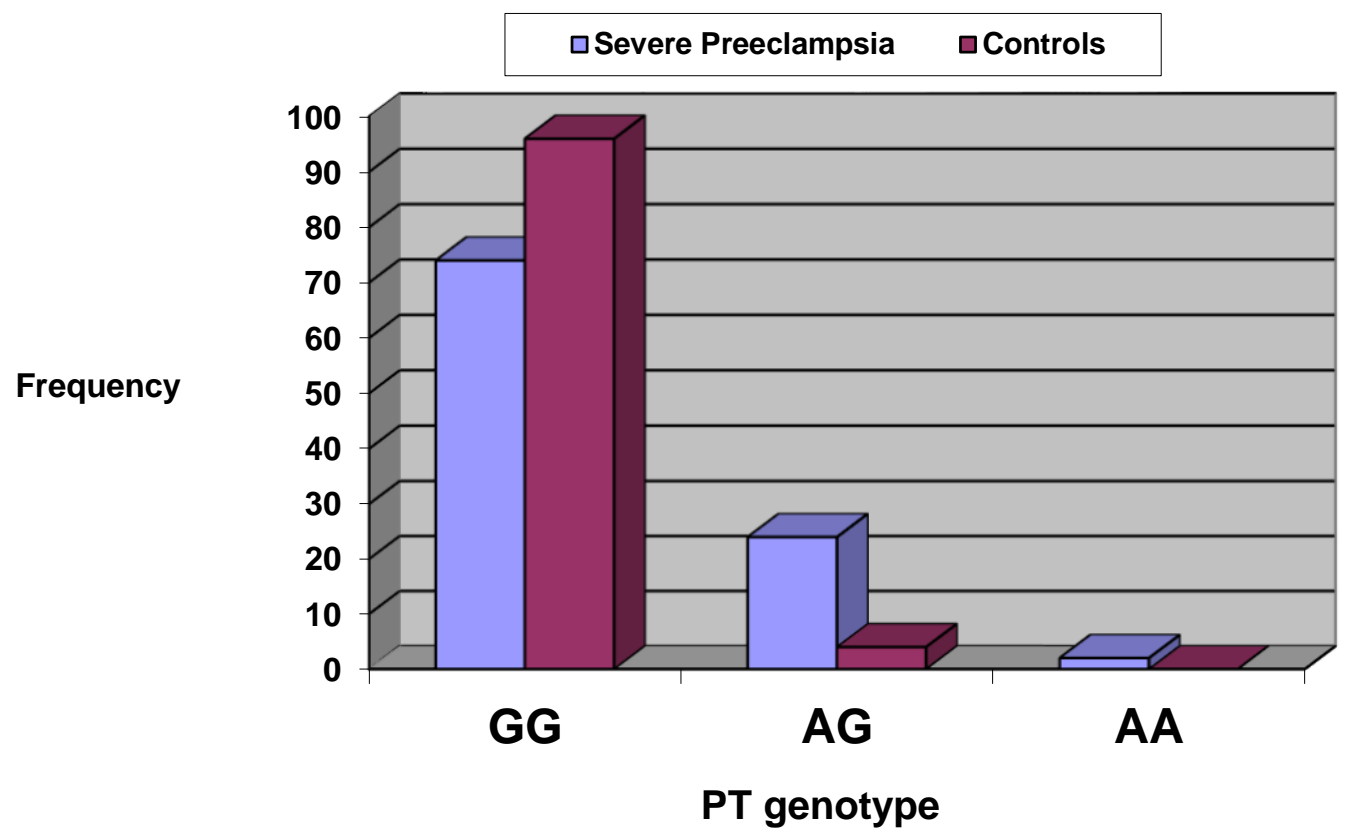

Fig. (2): Comparison between genotype allele in severe preeclampsic cases and healthy controls regarding their distribution and frequency of Prothrombin gene. 
Table (3): Comparsion between systolic blood pressure regarding to Prothrombin gene.

\begin{tabular}{|c|c|c|c|}
\hline & \multicolumn{3}{|c|}{ Genotypes } \\
\hline & $\begin{array}{c}\text { GG } \\
\mathbf{n}(\%)\end{array}$ & $\begin{array}{c}\text { GA } \\
\mathbf{n}(\%) \\
\end{array}$ & $\begin{array}{c}\mathbf{A A} \\
\mathbf{n}(\%) \\
\end{array}$ \\
\hline $\begin{array}{c}140-160 \\
(n=62)\end{array}$ & $47(75.8 \%)$ & $12(19.4 \%)$ & $3(4.8 \%)$ \\
\hline $\begin{array}{l}90-120 \\
(n=50)\end{array}$ & $48(96.0 \%)$ & $2(4.0 \%)$ & $0(0.0 \%)$ \\
\hline $\mathbf{P}$ & $0.003^{* * *}$ & $0.01 *$ & 0.2 \\
\hline $\begin{array}{c}>160 \\
(\mathrm{n}=30)\end{array}$ & $21(31.8 \%)$ & $7(10.6 \%)$ & $2(3.0 \%)$ \\
\hline $\begin{array}{r}90-120 \\
(n=50)\end{array}$ & $48(96.0 \%)$ & $2(4.0 \%)$ & $0(0.0 \%)$ \\
\hline $\mathbf{P}$ & $0.001 * *$ & $0.01 *$ & 0.1 \\
\hline
\end{tabular}

$\mathrm{n}=$ number of cases; $(\%)=$ percentage of cases.

Table (4): Comparison between diastolic blood pressure regarding to Prothrombin gene.

\begin{tabular}{|c|c|c|c|}
\hline & \multicolumn{3}{|c|}{ Genotypes } \\
\hline & $\begin{array}{c}\text { GG } \\
\mathbf{n}(\%)\end{array}$ & $\begin{array}{c}\text { GA } \\
\mathbf{n}(\%)\end{array}$ & $\begin{array}{c}\mathbf{A A} \\
\mathbf{n}(\%) \\
\end{array}$ \\
\hline $\begin{array}{l}90-110 \\
(n=32)\end{array}$ & $23(71.9 \%)$ & $6(18.8 \%)$ & $3(9.4 \%)$ \\
\hline $\begin{array}{c}60-90 \\
(n=50)\end{array}$ & $48(96.0 \%)$ & $2(4.0 \%)$ & $0(0.0 \%)$ \\
\hline $\mathbf{P}$ & $0.002 * *$ & 0.05 & 0.05 \\
\hline $\begin{array}{c}>110 \\
(n=60)\end{array}$ & $45(75.0 \%)$ & $13(21.7 \%)$ & $2(3.3 \%)$ \\
\hline $\begin{array}{c}60-90 \\
(n=50)\end{array}$ & $48(96.0 \%)$ & $2(4.0 \%)$ & $0(0.0 \%)$ \\
\hline $\mathbf{P}$ & $0.002 * *$ & $0.01 *$ & 0.4 \\
\hline
\end{tabular}

$\mathrm{n}=$ number of cases; $(\%)=$ percentage of cases.

Table (5): Frequency of mutations in both preeclampsic patients and controls.

\begin{tabular}{||ccccc||}
\hline Groups & $\begin{array}{c}\text { No } \\
\text { mutations } \\
\mathbf{n}(\%)\end{array}$ & $\begin{array}{c}\text { One } \\
\text { mutations } \\
\mathbf{n}(\%)\end{array}$ & $\begin{array}{c}\text { Two } \\
\text { mutations } \\
\mathbf{n}(\%)\end{array}$ & $\begin{array}{c}\text { Three } \\
\text { mutations } \\
\mathbf{n}(\%)\end{array}$ \\
\hline \hline $\begin{array}{c}\text { Cases } \\
(\mathrm{n}=92)\end{array}$ & $10(10.9 \%)$ & $31(33.7 \%)$ & $36(39.1 \%)$ & $14(15.2 \%)$ \\
$\begin{array}{c}\text { Controls } \\
(\mathrm{n}=50)\end{array}$ & $7(14.0 \%)$ & $21(42.0 \%)$ & $21(42.0 \%)$ & $1(2.0 \%)$ \\
$\mathrm{P}$ & 0.5 & 0.3 & 0.8 & $0.01 *$ \\
\hline
\end{tabular}

$\mathrm{n}=$ number of cases; $(\%)=$ percentage of cases significance. Significance using Fisher's Exact Test $* \mathrm{p}<0.05$ (significant), four mutations are: C677T, A1298C, Prothrombin gene and Factor V Leiden. 


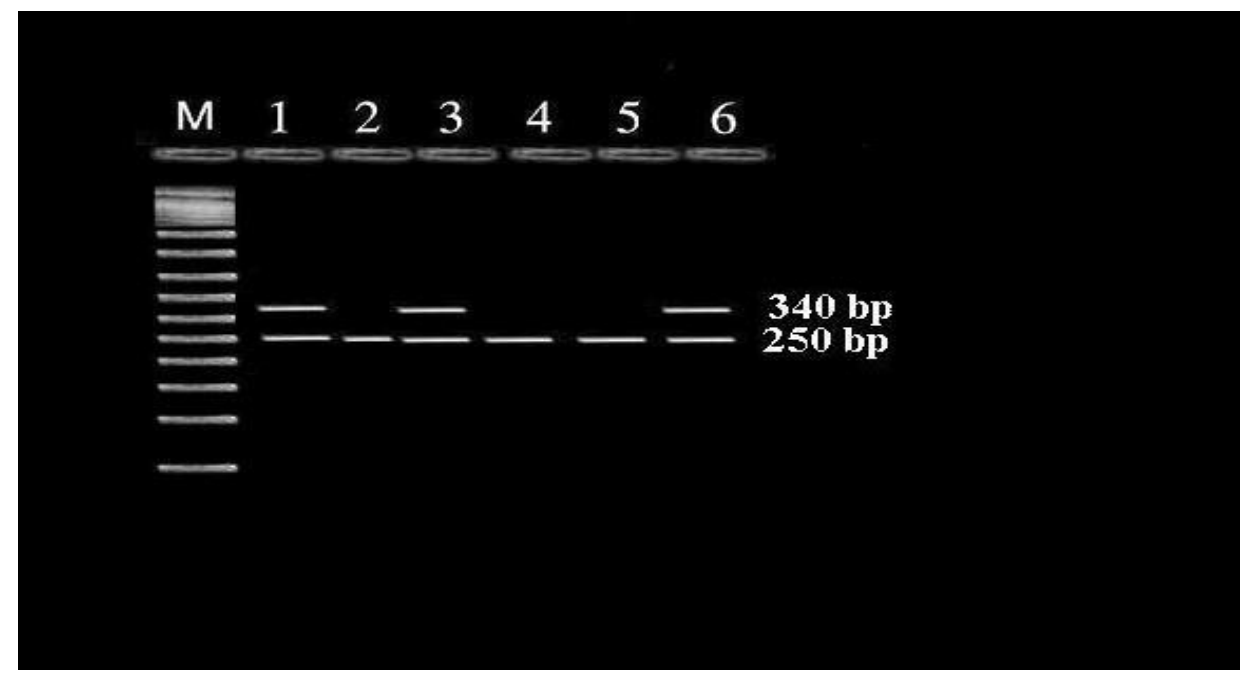

Fig. (3): Amplification of Prothrombin gene (G20210A) using primers for mutant A alleles (lanes 2,4 and 6) and normal $\mathrm{G}$ allele (lanes 1,3 and 5) showing positive bands (340bp), lane $\mathrm{M}$ indicates molecular marker, bands of size $250 \mathrm{bps}$ belongs to F IX used as internal controls; lane 1,2 represent case1; lane 3,4 represent case2 and lane 4,6 represent case3; case1,2 showed G/G normal homozygous and case3 showed A/A homozygous mutant.

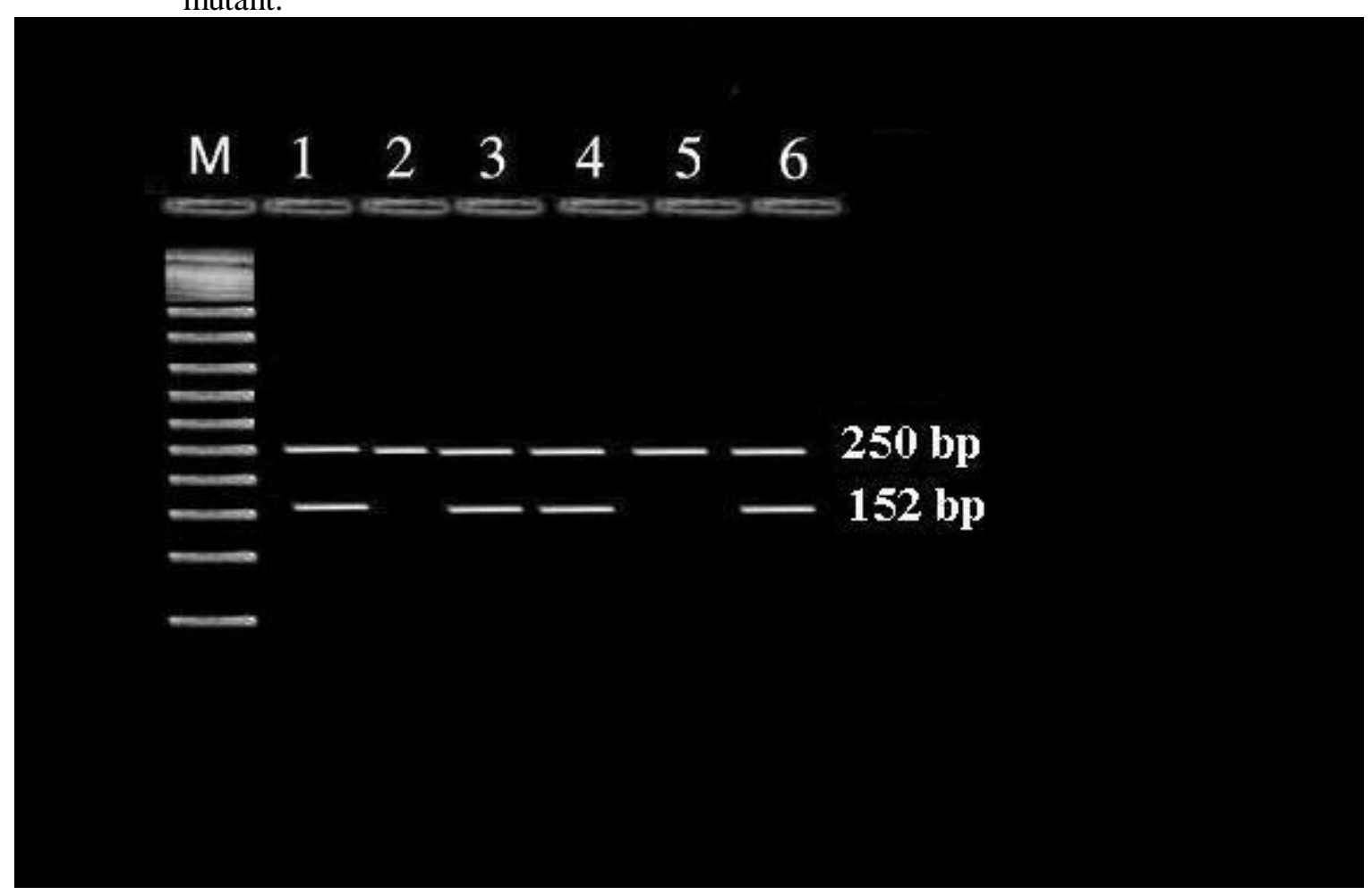

Fig. (4): Amplification of Factor V Leiden (G1691A) using primers for mutant A alleles (lanes 2,4 and 6) and normal $\mathrm{G}$ allele (lanes 1,3 and 5) showing positive bands (152bp), lane $\mathrm{M}$ indicates molecular marker, bands of size $250 \mathrm{bps}$ belongs to F IX used as internal controls; lane 1,2 represent case1; lane 3,4 represent case2 and lane 4,6 represent case3; case1 showed G/G normal homozygous, case2 showed G/A heterozygous mutant and case 3 showed A/A homozygous mutant. 


\section{Discussion:}

Preeclampsia is a common pregnancyrelated hypertension syndrome that poses a major risk of mortality and morbidity on both the woman and fetus. (11) It has been appreciated for almost 4 decades that it has a familial basis, although the exact mode of inheritance remains unclear. ${ }^{(12)}$ The pathophysiology of preeclampsia reflects widespread dysfunction of the maternal vascular endothelium. ${ }^{(13)}$, and vascular diseases such as diabetes, essential hypertension, and anti phospholipid syndrome predispose pregnant women to preeclampsia. This, together with the marked thrombotic tendency of some women with preeclampsia.$^{(14)}$, has suggested a number of candidate genes that may be involved in the pathophysiology of preeclampsia. ${ }^{(15)}$

The most common inherited thrombophilic disorders during pregnancy are mutations in Factor V Leiden (FVL), Prothrombin gene, and Tetrahydrofolate reductase. During the past decades, epidemiologic and case-control studies have evaluated the association between thrombophilias and adverse pregnancy outcome, specifically, preeclampsia and intrauterine fetal growth restriction. (16,17,18,19,20) $^{-1}$

Factor V Leiden (FVL) and the prothrombin gene mutations are the first and second most common genetic abnormalities associated with increased risk of deep venous thrombosis ${ }^{(6)}$ The risk of thrombotic events appears to be significantly higher among pregnant women with these mutations. ${ }^{(21,22,23)}$

The current study was done to identify polymorphism of Factor $\mathrm{V}$ Leiden and Prothrombin gene in women suffering from preeclampsia and compare between these polymorphic changes and other factors associated with preeclampsia and the implication of associated genotypes as risk factors for the development of preeclampsia.

The current study revealed that prothrombin gene mutation (heterozygous/AG) was highly significant among preeclampsic patients (20.7\%) compared with the controls (4.0\%), (OR 6.2, $\mathrm{P}=0.006$ ) with significance of allele $\mathrm{A}$, while normal prothrombin gene genotype (GG) was found highly significant in controls. So, genotype AG may be a risk marker for preeclampsia while genotype GG may be a protective one.
Factor V Leiden mutant (heterozygous AG) was found in $8.7 \%$ of preeclampsic patients and not present in any of the controls (OR 10.1, $\mathrm{P}=0.05$ ) with highly significant $\mathrm{A}$ allele, while normal genotype GG was found in $90.2 \%$ of patients and $100 \%$ of controls with significance of $\mathrm{G}$ allele in the controls.

Multiple case-control studies found a significantly higher prevalence of Factor V Leiden in women with preeclampsia (8\%-26\%) compared to women with normal pregnancies (2\%-10\%) with OR(2-6) . $24,25,26,27,28)$

Among the women with history of venous thromboembolism Gerhardt et al. ${ }^{(29)}$ found that the prevalence of factor $\mathrm{V}$ Leiden was $43.7 \%$ as compared with $7.7 \%$ among normal women, and the G20210A prothrombin gene mutation $16.9 \%$ as compared with $1.3 \%$.

On the other hand, Robert et al. (30) and Silver et al. ${ }^{(31)}$ showed that $3.8 \%$ women had the prothrombin gene mutation and they conclude that there was no association between the prothrombin G20210A mutation and pregnancy loss, preeclampsia, abruption, or SGA neonates in a low-risk, prospective cohort. Also, Stamatian et al. ${ }^{(32)}$ showed that the prevalence of the Factor V Leiden mutation was higher in the control group (10.2\%) as compared with the studied group $(8.3 \%)$. The G20210A mutation was not isolated in any of the groups.

Pregnancy complications associated with Factor V Leiden and other genetic thrombophilic mutations (e.g. Prothrombin G20210A and MTHFR C677T) are thought to be due to thrombosis of the uteroplacental vasculature. $^{(33,34,35)}$ The G20210A prothrombin gene mutation and factor $\mathrm{V}$ Leiden individually are associated with an increased risk of venous thromboembolism during pregnancy and the puerperium, and the risk among women with both mutations is disproportionately higher than that among women with only one mutation. ${ }^{(29)}$

Our results showed that Prothrombin gene mutation (homozygous/AA) was significant among women with mild preeclampsia $(\mathrm{P}=0.04)$ while heterozygous/AG was significant among women with severe preeclampsia $(\mathrm{P}=0.007)$ compared with the controls. Also, Factor V Leiden mutation (heterozygous/AG) was significant among mild preeclampsia $(\mathrm{P}=0.04)$ compared with the controls. 
Mello et al. ${ }^{(28)}$ reported that the prevalence of inherited or acquired thrombophilia was significantly higher in women with severe preeclampsia $(50.7 \%)$ compared with controls (17.2\%). In contrast, they found no association between thrombophilia and mild preeclampsia (16.7\% Vs. $14.9 \%$ in controls). Moreover, Gerhardt et al. ${ }^{(36)}$ found that women who are carriers of the G20210A Prothrombin gene mutation are at risk for early onset of severe preeclampsia.

In the present study, Prothrombin gene and Factor V Leiden polymorphism showed no significant difference in genotypes in relation to age of the patient ( $\leq 24$ years or $>24$ years), parity (primigravida or multigravida) or gestational age ( $\leq 36$ week or $>36$ week), while Prothrombin gene mutation (AA) was significant in patients with positive family history of preeclampsia $(\mathrm{P}=0.04)$.

A surprising finding of an Italian study is that patients with severe preeclampsia and positive thrombophilia work-up had a significantly higher rate of maternal complications such as onset of disease before $28^{\text {th }}$ week of gestation, abruptio placentae, disseminated intravascular coagulopathy, and acute renal failure compared with preeclamptic women without thrombophilia. In addition, severe preeclamptic women with thrombophilia were more likely to deliver at $<28$ weeks and had higher perinatal mortality compared with those without thrombophilia . ${ }^{(28)}$

Our results showed that Prothrombin gene and Factor V Leiden mutations (heterozygous/AG) were significantly associated with high systolic and diastolic blood pressure $(\mathrm{P}<0.05)$ while normal genotype GG (both genes) was significant in control compared with hypertensive patients. So, genotypes AG of both genes may be a risk factor for severe hypertension while genotype GG of both genes may be a protective marker from severe preeclampsia.

An important finding in this study is that multiple thrombophilic mutations were significantly higher in preeclamptic patients $(\mathrm{P}=0.01)$ while single mutation is not significant compared with the controls $(\mathrm{P}=0.5)$. In concordance with our results, Gerhardt $\boldsymbol{e t}$ al. ${ }^{(29)}$ reported that Prothrombin-gene mutation and Factor V Leiden individually are associated with an increased risk of venous thromboembolism during pregnancy and the puerperium, and the risk among women with both mutations is disproportionately higher than that among women with only one mutation.

Clearly not all women who carry a thrombophilic mutation suffer a pregnancy loss and perhaps it is those who carry multiple thrombophilic defects who are at greatest risk .37) Thepresence of a heterozygous Factor V Leiden or heterozygous G20210A mutation in the prothrombin gene is associated with a pregnancy-associated thrombotic risk of approximately 1 in 400. Thus, in pregnant carriers of either one of these mutations the risk of venous thromboembolism is low. A combination of the two genetic risk factors can increase the risk to a modest level of 1 in $25 .{ }^{(38)}$

Two small studies, from the same group of investigators, have reported that heparin thromboprophylaxis during pregnancy leads to a high live birth rate amongst women with a history of adverse pregnancy outcome and a thrombophilic defect. However, both studies were uncontrolled and the results must therefore be interpreted with caution. ${ }^{(39,40)}$

Moreover, low-molecular weight heparin was shown to improve pregnancy outcome in women with a history of one fetal loss and a constitutional thrombophilic disorder. ${ }^{(41)}$

\section{From the previous results, we can conclude that:}

1- Thrombophilic gene mutations including Prothrombin gene (heterozygous 20210/AG) and Factor V Leiden (heterozygous 1691/AG) are associated with genetic high risk factors for the development of preeclampsia.

2-Heterozygous AG of Prothrombin gene and Factor V Leiden may be considred as genetic risk markers for severe hypertension or predictors of severe preeclampsia.

3-Combination of thrombophilic gene mutations (Prothrombin gene and Factor V Leiden) raise the risk of preeclampsia than single thrombophilic defect.

\section{References:}

1- Chesley LC. (1984): History and epidemiology of preclampsia-eclampsia. Clin. Obstet. Gynecol., 27: 801-820.

2- Kaunitz AM, Hughes JM, Grimes DA, Smith JC, Rochat RW, Kafrissen ME (1985): Causes of maternal mortality in the United States. Obstet Gynecol., 65: 605-612. 
3- Sibai BM. (1990): Medical disorders in pregnancy, including hypertensive diseases. Curr.Opin. Obstet. Gynecol., 2: 13-22.

4- Kenny L, Baker PN. (1999): Maternal pathophysiology in preclampsia. Baillieres Best Pract. Res. Clin. Obstet. Gynaecol., 13: 59-75.

5- Rath W, Faridi A, Dudenhausen JW. (2000): HELLP syndrome. J. Perinat., Med. 28: 249-260.

6- Bertina RM, Koeleman BPC, Koster $T$. (1994): Mutation in blood coagulation factor $\mathrm{V}$ associated with resistance to activated protein $\mathrm{C}$. Nature, 369: 64-67.

7- Makris M, Preston FE, Beauchamp NJ.(1997): Co-inheritance of the 20210A allele of the prothrombin gene increases the risk of thrombosis in subjects with familial thrombophilia. Thromb Haemost., 78: 1426-1429.

8- Rosendaal FR (1999): Venous thrombosis: a multicausal disease. Lancet., 353: 1167-1173.

9- Ripoll L, Paulin D, Thomas S, Drouet LO(1997): Multiplex PCR-mediated site-directed mutagenesis for one-step determination of factor $\mathrm{V}$ Leiden and G20210A transition of the prothrombin gene. Thromb.Haemost., 78: 960-961.

10- Hezard N, Ceinillet-Lefebvre P, Gillot L, Potron G Nguyen P (1998): Multiplex ASA PCR for a simultaneous determination of factor $\mathrm{V}$ Leiden gene $\mathrm{G} \rightarrow \mathrm{A} 20210$ prothrombin gene and $\mathrm{C} \rightarrow \mathrm{T} 677$ MTHFR gene mutations. Thromb Haemost., 76: 651-662.

11- Broughton PipkinF(1995): The hypertensive disorders of pregnancy. BMJ., 311: 609-613.

12- Chesley LC, Annito JC, Cosgrove RA (1968): The familial factor in toxaemia of pregnancy. Obstet. Gynaecol., 32: 303-311.

13- Roberts JM, Taylor RN, Musci TJ, Rodgers GM, Hubel CA, McLaughlin MK (1989): Preeclampsia: an endothelial cell disorder. Am. J. Obstet. Gynecol., 161: 1200-1204.

14- Dekker G, de Vries JIP, Doelitzsch PM, HuiJgens PC, Von Blomberg BME, Jacobs C (1995): Underling disorders associated with severe early-onset preeclampsia. Am. J. Obstet. Gynecol., 173: 1042-1048.

15-Girling J, de Swiet M (1998): Inherited thrombophilia and pregnancy. Curr.Opin.ObstetGynecol., 10: 135-144.

16- Lee RM, Brown MA, Branch DW, Ward K, Silver RM (2003): Anticardiolipin and anti-B2 glycoprotein-I antibodies in preeclampsia. Obstet. Gynecol., 102: 294-300.

17- KujovichJL(2004): Hormones and pregnancy: thromboembolic risks for women. Br. J. Haematol., 126: 443-454.

18- Paidas MJ, Ku DH, Arkel YS (2004): Screening and mangement of inherited thrombophilias in the setting of averse pregnancy outcome. Clin. Perinatol., 31: 783-805.
19-Lin J, August P (2005): Genetic thrombophilias and preeclampsia. A meta-analysis. Obstet. Gynecol., 105: 182-192.

20-Miginini LE, Latthe PM, Villar J, Killy MD, Carroli G, Khan KS (2005): Mapping the theories of preeclampsia: the role of homocysteine. Obstet. Gynecol., 105: 411-425.

21-Bokarewa MI, Bremme K, Blomback M (1996): Arg506-Gln mutation in factor V and risk of thrombosis during pregnancy. Br. J. Haematol., 92: 473-478.

22-Hallak M, Senderowicz, J, Cassel A, Shapira C, Aghai E, Auslender R, Abramovici H (1997): Activated protein $\mathrm{C}$ resistance (factor $\mathrm{V}$ Leiden) associated with thrombosis in pregnancy. Am. J. Obstet. Gynecol., 176: 889-893.

23-Gerhardt A, Scharf RE, Beckmann MW, Struve S, Bender HG, Pillny M, Sandmann W, Zotz RB (2000): Prothrombin and factor V mutations in women with a history of thrombosis during pregnancy and the puerperium. N. Engl. J. Med., 342: 374-380.

24- Grandone E, Margaglione M, Calaizzo D, d Addedda M, Cappucci G, Vecchione G(1997): Factor V Leiden is associated with repeated and recurrent unexplained fetal losses. Thrombosis and Haemostasis, 77: 822-824.

25-Grandone E, Margaglione M, Colaizzo D, Cappucci G, Scianname N, Montanaro S, Paladini D, Martinelli P, Di Minno G (1999): Prothrombotic genetic risk factors and the occurrence of gestational hypertension with or without proteinuria. Thromb.Haemost., 81: 349-352.

26-Kupferminc MJ, Eldor A, Steinman N, Many A, Bar-Am A, Jaffa A, Fait G, Lessing JB (1999): Increased frequency of genetic thrombophilia in women with complications of pregnancy. N. Engl. J. Med., 340: 9-13.

27- Agorastos T, Karavida A, Lambropoulos A, Constantinidis T, Tzitzimikas S, Chrisafi S, Saravelos H, Vavilis D, Kotsis A, Bontis J (2002): Factor V Leiden and prothrombin G20210A mutations in pregnancies with adverse outcome. J. Matern. Fetal Neonatal Med .,12: 267-273.

28-Mello G, Parretti E, Marozio L, Pizzi C, Lojacono A, Frusca T, Tondi F, Borri P, Scarselli G, Sibai BM (2005): Thrombophilia is significantly associated with severe preeclampsia. Results of a large scale, care-controlled study. Hypertension, 46: 1270-1274.

29- Gerhardt A, Scharf RE, Beckmann MW, Struve S, Bender HG, Pillny M, Sandmann W, Zotz RB (2009): Prothrombin and factor V mutations in women with a history of thrombosis during pregnancy and the puerperium. Haemophilia, 15 (1): 377-379.

30-Robert M Silver, Yuan Zhao, Catherine Y Spong, BahaSibai, George WendelJr, Katharine Wenstrom, Philip Samuels, Steve N Caritis, Yoram 
Sorokin, MenachemMiodovnik, Mary J O'Sullivan, Deborah Conway, Ronald J Wapner (2009): Prothrombin gene G20210A mutation and Obstetric complications. Saudi Med. J., 30(10): 286290.

31- Silver RM, Zhao Y, Spong CY, Sibai B, Wendel G Jr, Wenstrom K, Samuels P, Caritis SN, Sorokin Y, Miodovnik M, O'Sullivan MJ, Conway D, Wapner RJ (2010): Prothrombin gene G20210A mutation and obstetric complications. Obstet. Gynecol., 115(1): 14-20.

32- Stamatian F, Caracostea G, Muresan D, Bartok I, Militaru M, Procopciuc L, Popp R, Trifa $A$ (2009): The evaluation of inherited thrombophilic conditions in patients with bleeding in the first trimester of pregnancy. MVH. Bioflux., 1(1): 9-17.

33-Cattaneo M, Tsai MY, Bucciarelli P (1997): A common mutation in the methylenetetrahydrofolate reductase gene C677T increases the risk for deepvein thrombosis in patients with mutant factor $\mathrm{V}$. Arterioscler. Thromb.Vasc. Biol., 17: 1662-1666.

34- Alhenc-Gelas M, Arnaud E, Nicaud V (1999): Venous thromboembolic disease and the prothrombin, methylenetetrahydrofolatereductase and factor $\mathrm{V}$ genes. Thromb.Haemost., 81: 506-510.

35-Lane DA, Grant PJ(2000): Role of hemostatic gene polymorphisms in venous and arterial thrombotic disease. Blood, 95: 1517-1532.

36- Gerhardt A, Goecke TW, Bekmann MW, Wagner KJ, Tutschek B, Willers R, Bender HG, Scharf RE, Zotz RB (2005): The G20210A prothrombin gene mutation and the plasminogen activator inhibitor (PAI-1) 5G/5G genotype are associated with early onset of severe preeclampsia. J. Thromb. Haemost., 3: 686-691.

37- Rai R, Backos M, Elgaddal S, Shlebak A, Regan $L$ (2002): Factor V Leiden and recurrent miscarriage-prospective outcome of untreated pregnancies. Human Reproduction, (17): 2; 442445.

38- Zotz RB, Gerhardt A, Scharf RE (2005): Pregnancy-associted venous thromboembolic disease: prediction, prevention, and therapy. J. Thromb. Haemost., 3(4): 778-793.

39-Brenner B, Hoffman R, Blumenfeld Z, Weiner $Z$, Younis JS (2000): Gestational outcome in thrombophilic women with recurrent pregnancy loss treated by enoxaparin. Thromb. Haemost., 83: 693697.

40- Younis JS, Ohel G, Brenner B (2000): The effect of thrombophylaxis on pregnancy outcome in patients with recurrent pregnancy loss associated with factor $\mathrm{V}$ Leiden mutation. Br. J. Obstet. Gynaecol., 107: 415-419.

41-Gris JC, Mercier E, Quere I, LavigneLissalde G, Cochery-Nouvellon E, Hoffet M, Ripart-Neveu S, Tailland ML, Dauzat M, Mares $P$ (2004): Low-molecular-weight heparin versus lowdose aspirin in women with one fetal loss and a constitutional thrombophilic disorder. Blood, 103: 3695-3699. 